\title{
Carta de Apresentação do Dr. Charles Zarca
}

Dr. Charles Zarca é angiologista francês hà 25 anos e pioneiro da escleroterapia com espuma desde 1988. Bastante conhecedor da escleroterapia clássica estava limitado pela potência dos esclerosantes líquidos ficando limitado ao tratamento esclerosante de pequenas e médias veias.

Quando surgiu a escleroterapia com espuma Dr Zarca se interessou rapidamente pelas novas possiblidades do método junto com outros colegas franceses da região em que mora, como Jean-Pierre GOBIN, Jean-Luc GILLET e Gilles GACHET. Participou da fundação e é o membro da diretoria do Club-mousse.com e do Consenso de Grenoble com o espírito de divulgar e melhorar o método da escleroterapia com espuma.

Ele nos diz que sente-se honrado e feliz em participar do SIF2013 em Belo Horizonte e nos fará duas apresentações de alto nível científico:

- estudo randomisado sobre os efeitos da compressão elástica e da dor após escleroterapia;

- análise das complicações (distúrbios visuais) após escleroterapia.

\section{Dr. Charles Zarca}

www.club-mousse.com

charcraz74@gmail.com

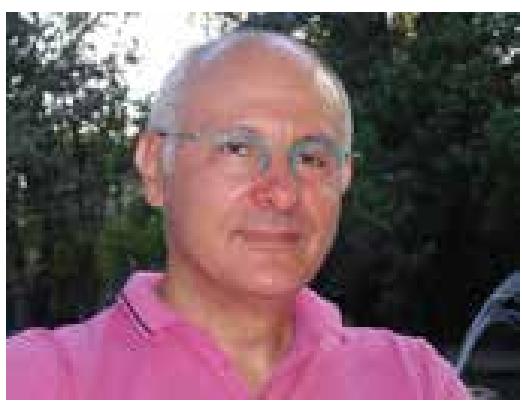

